tion, then decreased slowly. The radioactivity, mainly contained in the extract for the first hours of the experiment, was quite totally recovered in the protein-bound fraction 48 hours after.

Labelling of free sulphur amino acids in the blood was low (about I p. Ioo of the labelling of the whole free fraction).

The radioactivity of the soluble fraction (TCA) of digesta increased very rapidly after the injection. It reached a maximum about $I$ hour after the introduction of the tracer $\left(329 \cdot 10^{6}\right.$ $\mathrm{DPM} / \mathrm{kg}$ wet content), then decreased very much $\left(53 \cdot{ }^{\prime} \mathrm{I}^{6} \mathrm{DPM} / \mathrm{kg}\right)$ after $6.30 \mathrm{~h}$. Methionine was the only component labelled in this fraction during the first hour, then followed cystine. On the other hand, the radioactivity of the extraction insoluble increased slowly after the beginning of the experiment and reached its maximum at about the $\mathrm{I} 8$ th hour $\left(206 \cdot 10^{6} \mathrm{DPM} / \mathrm{kg}\right) ;$ the ${ }^{35} \mathrm{~S}$ was incorporated into methionine and cyst(e)ine. Maximum labelling of methionine in the extraction insoluble was obtained 18 hours after the injection ( $143 \cdot{ }^{\cdot} \mathrm{IO}^{6} \mathrm{DPM} / \mathrm{kg}$ ) whereas for cystine it was only recorded after 24 hours $\left(13 \cdot 10^{6} \mathrm{DPM} / \mathrm{kg}\right)$.

A significant proportion of the ${ }^{35} \mathrm{~S}$ introduced into the rumen as methionine left this organ as free methionine or incorporated into bacterial proteins and entered directly the intestine. The rest was quickly metabolized and the sulphur components obtained were absorbed by the blood or used on the spot by microorganisms in order to synthetize methionine and cystine.

\title{
UTILISATION DIGESTIVE COMPAREE DE L'ORGE, DE LA BANANE VERTE ET DE LA BANANE ENSILÉE CHEZ LA CHẼVRE
}

\section{PONCET}

\author{
Station de Recherches sur l'Élevage des Ruminants, \\ Centre de Recherches de Clermont Ferrand, \\ Theix 63110 Beaumont
}

Une partie appréciables des bananes vertes ne peut pas être exportée ou utilisée dans l'alimentation humaine par les pays producteurs. Or, leur matière sèche (2o p. Ioo de la matière frâ̂che) a une composition voisine de celle d'un aliment concentré, pauvre en azote (67 p. Ioo d'amidon, 3 p. Ioo de cellulose brute et 0,9 p. Ioo d'azote).

Pour étudier les caractéristiques de la digestion de cet aliment par le ruminant, nous avons utilisé des chèvres portant une canule du rumen et une canule réentrante au niveau du duodénum.

Nous avons comparé la banane verte ou ensilée après hachage à de l'orge, dans des rations ayant par ailleurs une petite quantité de fourrages verts de Pangola (Digitaria decumbens) et de tourteau de soja; le fourrage représentait environ $20 \mathrm{p}$. Ioo de la matière sèche ingérée.

Pour des quantités ingérées de 800 à $900 \mathrm{~g} / \mathrm{j}$, la digestibilité de la matière organique est élevée, comparable dans les trois régimes et même légèrement supérieure avec la banane $(82 \mathrm{p}$. Ioo contre 80 p. Ioo avec l'orge).

A ces niveaux d'ingestion ( $400 \mathrm{~g}$ d'amidon ingéré/j), la digestibilité de l'amidon de banane est quasi totale ( $99 \mathrm{p}$. Ioo pour l'amidon de banane verte, $96 \mathrm{p}$. Ioo pour la banane ensilée).

Le coefficient d'utilisation digestive de l'azote est plus faible avec les régimes de banane verte qu'avec les régimes d'orge et de banane ensilée (CUD des matières azotées totales : 54,4 p. Ioo, 78 p. I0o, 75 p. Ioo respectivement). Pour expliquer ce résultat, on peut mettre en cause l'action des tanins dont la banane verte est riche. 
La proportion de matière organique qui disparaît avant l'intestin, exprimée en p. roo de la matière organique digestible, est de $: 76 \mathrm{p}$. Ioo avec le régime d'orge pour des quantités ingérées de $800 \mathrm{~g} / \mathrm{j}$; respectivement $93 \mathrm{p}$. roo et $86 \mathrm{p}$. Ioo pour des quantités de matières organiques ingérées de $\mathrm{I}$ ooo $\mathrm{g} / \mathrm{j}$ et de $7^{\circ 0} \mathrm{~g} / \mathrm{j}$ avec les régimes de banane verte et de banane ensilée.

Aux niveaux d'ingestion considérés (450 $\mathrm{g}$ d'amidon/ $\mathrm{j}$ ), l'amidon de banane passe dans l'intestin en quantité plus importante que l'amidon d'orge, qui est entièrement digéré dans le rumen ; 98,9 p. Ioo de l'amidon digestible disparaît dans le rumen avec l'orge contre 93 et 95 p. Ioo pour des régimes de banane verte et de banane ensilée.

Dans le cas de l'orge, il passe $93 \mathrm{~g}$ de matières azotées totales par jour au niveau du duodénum et pour une ingestion de $\mathrm{I} 37 \mathrm{~g}$; avec les régimes de banane verte, ces chiffres sont de $86 \mathrm{~g}$ de matières azotées totales pour une ingestion de IO$_{4} \mathrm{~g}$ et pour la banane ensilée, $83 \mathrm{~g}$ pour une ingestion de $77 \mathrm{~g}$ de matières azotées totales.

Avec la banane, les fermentations au niveau du rumen sont moins intenses et plus régulières au cours de la journée qu'avec les régimes d'orge ( $\mathrm{AGV}$ totaux: $127 \mathrm{~m}$-eq/l avec l'orge, I I 5 et I I I $\mathrm{m}$-eq/l avec la banane verte ou la banane ensilée) ; les quantités de bases volatiles totales libérées sont pratiquement nulles dans le cas de la banane et de l'ordre de $20 \mathrm{mg}$ d'azote/roo $\mathrm{ml} \mathrm{de} \mathrm{jus}$ dans le cas des régimes d'orge.

\section{SUMMARY}

\section{COMPARISON OF THE DIGESTIBILITY OF BARLEY, UNRIPE BANANA AND SILAGED BANANA IN THE GOAT}

An appreciable part of the unripe bananas cannot be exported or used for human nutrition by the producing countries. Now, their dry matter ( $20 \mathrm{p}$. Ioo of wet matter) has a composition close to that of a nitrogen low concentrate food (67 p. roo starch, 3 p. roo crude fiber and 0.9 p. Ioo nitrogen).

In order to study the characteristics of digestion of this food in the ruminant, we used goats fitted with a rumen cannula and a duodenal reentering cannula.

We compared unripe or silaged banana after cutting, with barley, in some diets including also a small quantity of Pangola (Digitaria decumbens) green forages and soyabean-oil meal ; the forage represented about $20 \mathrm{p}$. 100 of the dry matter intake.

For intakes of 800 to $900 \mathrm{~g} / \mathrm{d}$, digestibility of the organic matter was high, and comparable in the three diets and even slightly higher with banana ( $82 \mathrm{p}$. Ioo versus $80 \mathrm{p}$. Ioo with barley).

With such intake levels ( $400 \mathrm{~g}$ ingested starch/d), digestibility of the banana starch was almost total ( $99 \mathrm{p}$. 100 with unripe banana starch, $96 \mathrm{p}$. I00 with silaged banana.)

The apparent digestibility coefficient of nitrogen was lower with unripe banana diets than with barley and silaged banana diets (ADC of total crude protein : 54.4 p. 100, $7^{8}$ p. 10o, 75 p. 10o, respectively). This result may be explained by the effect of the high tanning content in unripe banana.

The proportion of organic matters disappearing before the intestine expressed in p. Ioo of digestible organic matter was $76 \mathrm{p}$. Ioo with the barley diet at an intake level of $800 \mathrm{~g} / \mathrm{d}$ and 93 p. I00 and 86 p. Ioo respectively when the intake of organic matters was $1000 \mathrm{~g} / \mathrm{d}$ and $700 \mathrm{~g} / \mathrm{d}$ with unripe banana and silaged banana.

With the considered intake levels ( $450 \mathrm{~g}$ starch/d), the banana starch entered the intestine in larger amounts than the barley starch that is entirely digested in the rumen; with barley 98.9 p. Ioo of the digestible starch disappeared in the rumen versus 93 and $95 \mathrm{p}$. Ioo with unripe and silaged bananas.

In the case of barley, $93 \mathrm{~g}$ of crude protein per day entered the duodenum after an intake 
of $137 \mathrm{~g}$; with unripe banana these data were $86 \mathrm{~g}$ of crude protein after an intake of ro4 $\mathrm{g}$ and with silaged banana, $83 \mathrm{~g}$ following an intake of $77 \mathrm{~g}$ of total crude protein.

With banana, the fermentations in the rumen were less important and more regular during the day than with barley diets (total VFA; I $27 \mathrm{~m}$ eq/l with barley, I 5 and I I. $\mathrm{m}$ eq/l with unripe or silaged banana); the amounts of total volatile bases released were practically non existent in the case of banana and about $20 \mathrm{mg}$. nitrogen/ $100 \mathrm{ml}$ of juice in the case of barley diets.

\title{
MORPHOLOGIE INTESTINALE CHEZ LA LAPINE GESTANTE ET ALLAITANTE SELON LE NIVEAU D'ALIMENTATION
}

\author{
F. LEBAS et J.-P. LAPLACE* \\ Station de Recherches sur l'Élevage des Porcs, \\ * Laboratoire de Physiologie de la Nutrition, \\ Centre national de Recherches zootechniques, I. N.R. A., \\ 78350 Jouy en Josas
}

L'existence chez nombre de mammifères de modifications morphologiques du tube digestif au cours du cycle de reproduction est un fait unanimement reconnu. Une revue détaillée de ces phénomènes a été réalisée par FELL ( ${ }^{1}$ ), principalement dans le cas de la brebis, de la ratte et de la souris. Cependant, l'allure de ces phénomènes est loin d'être univoque, laissant place à de nombreuses différences inter-spécifiques. L'évolution des mensurations viscérales au cours de la croissance ayant été précisée antérieurement $\left({ }^{2}\right)$, nous avons abordé dans la présente étude les modifications de poids et de longueur de l'intestin grêle au cours d'un cycle de reproduction chez la lapine.

A compter de la saillie, les lapines ont été soit nourries à volonté jusqu'au sevrage, soit rationnées à $140 \mathrm{~g} /$ jour d'un même aliment pendant la gestation puis alimentées à volonté dès la mise bas. Cinq lapines ont été abattues aussitôt après la saillie ; 5 lapines par niveau d'alimentation ont été sacrifiées à chacun des 6 stades suivants : 10, 21 et 28 jours de gestation ; 10, 21 et 32 jours après la mise-bas. Les techniques de mesure ont été décrites antérieurement $\left({ }^{2}\right)$.

La longueur de l'intestin grêle est, au $28 \mathrm{e}$ jour de la gestation, accrue de I I p. Ioo chez les lapines rationnées, et réduite de $9 \mathrm{p}$. Ioo chez les lapines ad libitum par rapport au stade saillie. La longueur culmine pour les 2 populations ro jours après la mise bas. Le poids de l'intestin grêle chez les lapines ad libitum est réduit au cours de la gestation ( I I et $14 \mathrm{p}$. Ioo respectivement à $2 \mathrm{r}$ et 28 jours), et accru de 4I p. Ioo 2I jours après la mise bas. Chez les lapines rationnées on n'observe pas de régression pendant la gestation, et un moindre accroissement pondéral durant l'allaitement (27 p. Ioo au $2 \mathrm{I}^{\mathrm{e}}$ jour). La seule modification significative de la longueur du cæcum et du côlon est une réduction de 13 p. Ioo au $28^{\circ}$ jour de gestation de la longueur cæacale chez les lapines ad libitum. Une perte de poids importante du cæcum au cours de la gestation est observée chez toutes les lapines. Elle atteint au $28 \mathrm{e}$ jour respectivement 29 et $3 \mathrm{I}$ p. roo chez les lapines rationnées et ad libitum. Le cæcum retrouve et conserve son poids initial dès le roe jour après la mise bas. Le poids du côlon est toujours réduit pendant la gestation, en particulier chez les lapines ad libitum ( $2 \mathrm{I}$ p. IOo au $28 \mathrm{e}$ jour). Le poids initial est rapidement regagné dès les Io premiers jours de lactation, cette valeur n'étant ensuite guère dépassée.

Globalement, on peut retenir que le rationnement de la lapine pendant la gestation tend à 